\title{
Health Education with Audiovisual Media and Relaxation Massage in Lowering Blood Pressure and Improved Sleep Quality for the Elderly
}

\author{
I. Wayan Mustika*, Ketut Sudiantara, Agus Sri Lestari \\ Department of Nursing, Politeknik Kesehatan Kementerian Kesehatan Denpasar, Denpasar, Indonesia
}

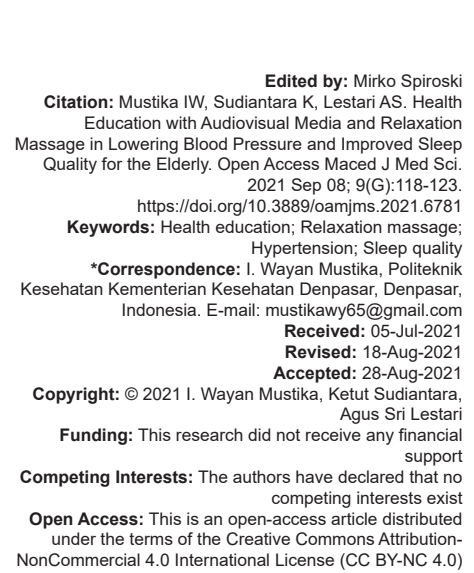

\section{Introduction}

Hypertension or high blood pressure is an increase in systolic blood pressure of more than $140 \mathrm{mmHg}$ and diastolic blood pressure of more than $90 \mathrm{mmHg}$ on two measurements with an interval of $5 \mathrm{~min}$ in a moderate or calm state. Increased blood pressure that lasts for a long time (persistent) can cause damage to the kidneys (kidney failure), heart (coronary heart disease), and brain (causing stroke) if not detected early and receive adequate treatment [1], [2].

According to a report by the World Health Organization or $\mathrm{WHO}$, hypertension is the number 1 cause of death in the world. Data in 2010 in the United States shows that $28.6 \%$ of adults aged 18 years and over suffer from hypertension [3], [4], [5]. According to Riskesdas data in 2013, the prevalence of hypertension in Indonesia was $26.5 \%$ [2] According to data from the Bali Provincial Health Office based on blood pressure measurements of residents 18 years of age, the highest were Buleleng (30.2\%), Gianyar

\begin{abstract}
BACKGROUND: The aging process results in a progressive decline in physiological functions with age, including a

AIM: The purpose of this study was the effect of health education with audiovisual methods and relaxation massage presure and sleep quality disorders in the elderly.

in this study is the elderly who are included in the elderly age group, namely, $>50$ years in Selemadeg District, Tabanan Regency. The sample size is 90 elderly, determined based on the results of previous using audiovisual media and Relaxation Massage and the dependent variable is blood pressure. Data collection Multivariate ANOVA test.

The blood pressure of the treatment group before the intervention m $(53.3 \%)$, and after the intervention most of the blood pressure improved to normal $(57.8 \%)$, and this result was and after the intervention improved sleep quality in the good category $(53.3 \%)$, and this result was statistically significant $(0.000)$.
\end{abstract}

CONCLUSION: It is concluded that the provision of health education with audiovisual methods and massage relaxation can reduce blood pressure and improve sleep quality in the elderly.

$(20.8 \%)$, and Klungkung $(11.7 \%)$ [6]. Based on the measurement of blood pressure for residents 18 years of age conducted by the Gianyar Regency Health Office in 2019, the highest hypertension/high blood pressure sufferer in Gianyar Regency is Sukawati II Health Center (73.68\%)[7], [8], [9], [10].

Hypertension is a common cause of disturbed sleep patterns, due to structural and functional changes in the peripheral vascular system [11]. The aging process will cause a decline in various organ functions in the elderly, such as a decline in the musculoskeletal system which will cause an elderly person to slow down his movements, muscles become cramped, tremors, joints become stiff, and the onset of pain. Mental and psychosocial changes will affect motivation in the elderly. All these changes become obstacles for the elderly to carry out activities independently [12]. The Indonesian government has made efforts to control hypertension through the PROLANIS program (Chronic Disease Control Program). PROLANIS is a health service system and a proactive approach that is implemented in an integrated manner involving 
Participants, Health Facilities, and BPJS Health in the context of health care for BPJS Health participants who suffer from chronic diseases to achieve optimal quality of life with effective and efficient health care costs. The goal of PROLANIS is to encourage participants with chronic diseases to achieve optimal quality of life with an indicator of $75 \%$ of registered participants visiting the First Level Health Facilities having "good" results on specific examinations for Type 2 diabetes mellitus (DM) and Hypertension according to the relevant Clinical Guidelines so as to prevent disease complications [13], [14].

\section{Materials and Methods}

This type of research is an experimental research (community trial) with a pretest-posttest control group design [15]. The target population in this study is the elderly who are included in the elderly age group, namely $>50$ years in Selemadeg District, Tabanan Regency. The sample size is 90 elderly, determined based on the results of previous studies with a standard deviation $(\sigma)=0.51$, the difference in the mean of cognitive changes $(\mu 1-2)=0.30$. It is divided into two groups, the treatment group and the control group [16]. The independent variable is health education using audiovisual media and Relaxation Massage and the dependent variable is blood pressure. Data collection tools in the form of sphygmomanometer, observation sheet. Data analysis used independent t-test, paired t-test, and Multivariate ANOVA test [15].

\section{Results}

\section{Characteristics of research subjects}

Table 1 shows the description of the results of the study on the characteristics of the age group, the highest percentage is the age group of 60-74 years by $40 \%$ of the control group and $51.1 \%$ of the treatment group. Based on gender in the control and treatment groups, the highest percentage was female $(57.8 \%$ and $68.9 \%$ ). The description of the highest economic status presentation was moderate economic status, which was $66 \%$ in the control group and $71 \%$ in the treatment group. The description of disease incidence comorbidities of all elderly the percentage of the elderly who do not have comorbidities is higher than those who have comorbidities, namely, $62.2 \%$ of the control group and $66.7 \%$ of the treatment group.
Table 1: Characteristics of research subjects in the control and treatment group

\begin{tabular}{lll}
\hline Variable & Control $\mathrm{n}(\%)$ & Treatment $\mathrm{n}(\%)$ \\
\hline Age (year) & $17(37.8)$ & $14(31.1)$ \\
$50-59$ & $18(40.0)$ & $23(51.1)$ \\
$60-74$ & $10(22.2)$ & $8(17.8)$ \\
$>74$ & $19(42.2)$ & $14(31.1)$ \\
Gender & $26(57.8)$ & $31(68.9)$ \\
$\quad$ Men & & \\
$\quad$ Woman & $9(14.1)$ & $8(17.8)$ \\
Economic status & $30(66.7)$ & $32(71.1)$ \\
$\quad$ Good & $6(13.3)$ & $5(11.1)$ \\
Enough & & $15(33.3)$ \\
Less & $17(37.8)$ & $30(66.7)$ \\
co-morbidities & $28(62.2)$ & \\
$\quad$ There is &
\end{tabular}

Comparison of blood pressure before and after intervention in treatment and control groups

Table 2 shows the description of the results of blood pressure measurements in the elderly after the intervention in the control group before the intervention most had Grade I hypertension (57.8\%), and after the intervention most of them still had Grade I hypertension $(60.0 \%)$, but the results there is no statistical difference (0.570). While in the treatment group before the intervention, most of them had Grade hypertension (53.3\%), and after the intervention most of them experienced an improvement in blood pressure to normal $(57.8 \%)$, and this result was statistically significant (0.000).

Table 2: Blood pressure results of control and treatment group

\begin{tabular}{lllllll}
\hline Blood pressure & Control & & Score & \multicolumn{2}{l}{ Treatment } & \multirow{2}{*}{ Score $\mathrm{p}$} \\
\cline { 2 - 5 } & Pre-test & Post-test & $\mathrm{p}$ & \multicolumn{2}{l}{ Pre-test $\mathrm{n}$ Post-test } & \\
& $\mathrm{n}(\%)$ & $\mathrm{n}(\%)$ & & $(\%)$ & $\mathrm{n}(\%)$ & \\
\hline Normal & $5(11.1)$ & $4(8.9)$ & 0.570 & $4(8.9)$ & $26(57.8)$ & 0.000 \\
Grade I hypertension & $26(57.8)$ & $27(60.0)$ & $24(53.3)$ & $15(33.3)$ & \\
Grade II hypertension & $12(26.7)$ & $9(20.0)$ & $14(21.9)$ & $3(6.7)$ & \\
Grade III hypertension & $2(4.4)$ & $5(11.1)$ & $3(4.7)$ & $1(2.2)$ & \\
\hline
\end{tabular}

Comparison of sleep quality before and after intervention in the treatment and control groups

Table 3 shows that the control group before the intervention mostly had poor sleep quality (57.8\%), and after the intervention only $28.9 \%$ of the elderly had good sleep quality, but there was no statistical difference between these results $(0.102)$. While in the treatment group before the intervention, most of them had poor sleep quality (46.7\%), and after the intervention most had improved sleep quality in the good category (53.3\%), and this result was statistically significant (0.000).

Table 3: Results of sleep quality in control and treatment groups

\begin{tabular}{|c|c|c|c|c|c|c|}
\hline \multirow[t]{2}{*}{ Sleep quality } & \multicolumn{2}{|l|}{ Control } & \multirow{2}{*}{$\begin{array}{l}\text { Score } \\
\text { p }\end{array}$} & \multicolumn{2}{|l|}{ Treatment } & \multirow[t]{2}{*}{ Score $p$} \\
\hline & Pre-test n (\%) & Post-test n (\%) & & $\begin{array}{l}\text { Pre-test } \mathrm{n} \\
(\%)\end{array}$ & $\begin{array}{l}\text { Post-test } \\
\mathrm{n}(\%)\end{array}$ & \\
\hline Very good & $2(4.4)$ & $2(4.4)$ & 0.102 & $1(2.2)$ & $18(40.0)$ & 0.000 \\
\hline Good & $8(17.8)$ & $13(28.9)$ & & $4(8.9)$ & $24(53.3)$ & \\
\hline Less & $26(57.8)$ & $27(60.0)$ & & $21(46.7)$ & $3(6.7)$ & \\
\hline Very less & $9(20.0)$ & $3(6.7)$ & & $19(42.2)$ & 0 & \\
\hline
\end{tabular}




\section{Discussion}

Table 1 based on sex, the control and treatment groups were mostly female $(57.8 \%$ and $68.9 \%$, respectively), the life expectancy of women at birth was higher than that of men, at 4.6 years. The average female longevity was in Europe (7.0 years) and in Latin America and the Caribbean (6.6 years), and the lowest was in Africa (3.3 years) and Asia (3.9 years). A consequence of women's greater longevity is a female-dominated elderly population, where in 2017, women accounted for $54 \%$ of the global population aged 60 years or over and $61 \%$ of the overall elderly age 80 or older. National Institute on Aging the increasing prevalence of hypertension related to age is due to changes in the structure and function of arteries during the aging process [17]. As systolic blood pressure increases gradually throughout life, diastolic blood pressure peaks and plateaus in late middle age, then decreases slightly thereafter [17]. Increased factors, including body weight, and levels of glukosa, trigliserida, and albumin in the blood also increases the risk of hypertension in the elderly [18]. In this study, most of the control and treatment groups had poor sleep quality $(57.8 \%$ and $46.7 \%$, respectively). Sleep disorders such as sleep-disordered breathing, sleep duration, and sleep structure can affect neurohormonal axes, including the sympathetic nervous system, contributing to elevated blood pressure, and hypertension. Epidemiological studies have also found that sleep deprivation and/or short sleep duration are associated with the prevalence and incidence of hypertension, and the association is most often found in premenopausal women [19]. A case-control polysomnographic study showed that the severity of hypertension was associated with shorter sleep duration, lower sleep efficiency, and less rapid eye movement (REM) sleep [20]. Aging is defined as a progressive decline in physiological function with age, including a decrease in productivity. In most developing countries, old age begins to appear at the point when active contributions to society cannot be made [21]. At the biological level, aging occurs as a result of the accumulation of various molecular and cellular damage over time. This leads to a gradual decline in physical and mental capacities, a greater risk of disease, and ultimately, death. However, these changes are not linear or consistent. In addition to biological changes, aging is also associated with life transitions such as retirement, relocation to more appropriate housing, and the death of friends and partners [4]. The number of elderly populations in developing countries is projected to increase by $140 \%$ compared to a $51 \%$ increase in developed countries [17]. National Institute on Aging, (2007) Indonesia is a developing country that is entering the era of an aging structured population, because the number of people aged 60 years and over has exceeded seven percent [5]. In this study, most of the research subjects from the control and treatment groups were in the age group of $60-74$ years. By 2050 , the world's elderly population aged over 60 years is estimated to be 2 billion, which is an increase from 900 million in 2015 [4] (WHO, 2018). Longer life brings with it opportunities, not only for parents and their families, but for society as a whole. The elderly can also contribute in many ways to their families and communities. However, the extent of these opportunities and contributions is highly dependent on one factor, namely, health [4].

Table 2 shows the results of statistical analysis obtained significant results, namely, $p=0.000<0.05$. The description of the high rate of hypertension is in line with increasing age caused by structural changes in large blood vessels, so that blood vessels become narrower and blood vessel walls become stiff, as a result of which is an increase in systolic blood pressure [22]. Hasurungan research in Rahajeng and Tuminah found that in the elderly compared to the age of 55-59 years with the age of 60-64 years there was an increase in the risk of hypertension by 2.18 times, aged $65-69$ years 2.45 times, and age $>70$ years 2.97 times [22]. The elderly are often affected by hypertension caused by stiffness in the arteries so that blood pressure tends to increase. In addition, the cause of hypertension is also due to lifestyle, which is more important, the possibility of an increase in high blood pressure due to increasing age is greater in people who consume a lot of foods that contain lots of salt [23]. Hypertension often results in a dangerous situation because it is often not realized and often does not cause significant complaints until one day complications occur, such as the risk of stroke, kidney failure, heart disease, and heart attack [24]. Untreated hypertension can damage organs such as the heart, brain, kidneys, and eyes, can cause premature death, causing lifelong inability to carry out activities [3]. Based on this, one of the preventions of hypertension is health education with audio-visual media because it is more interesting and more effective. Audio-visual media involves two senses, namely, the senses of sight and hearing which can maximize the reception of information in providing education to people with hypertension [25]. The decrease in the incidence of hypertension in the treatment group subjects after being given audiovisual health education interventions and message relaxation showed the effectiveness of this model.

Table 3 shows the results of statistical analysis obtained significant results, namely, $p=0.000<\alpha 0.05$. This situation is found in some literature which states that as many as $50 \%$ of adults complain of difficulty initiating or maintaining sleep. The prevalence of insomnia is higher in the older population than in the younger population. The overall prevalence of insomnia symptoms ranges from $30 \%$ to $48 \%$ in the elderly, while the prevalence of insomnia disorders ranges from $12 \%$ to $20 \%$ [26]. Along with many physiological changes in aging, significant changes also occur in sleep and circadian rhythms throughout life. The natural shortening of total sleep time in the elderly population can result 
in unrealistic expectations about sleep duration, giving rise to anxiety that can lead to or exacerbate insomnia. Beginning in middle age, adults spend less time in slow-wave sleep and REM sleep. Sleep efficiency continues to decline after passing the age of 60 years. Insomnia is associated with significant morbidity if left untreated. The elderly population with insomnia had a $23 \%$ increased risk of developing depressive symptoms. One study noted $44 \%$ of elderly patients with persistent insomnia after 6 months compared with $16 \%$ of patients without insomnia. Insomnia and mental disorders such as depression and anxiety have a twoway relationship [27]. The decrease in sleep quality disorders in the subjects of the treatment group after being given audiovisual health education interventions and message relaxation shows the effectiveness of this model.

\section{Implementation of health education using audiovisual media and relaxation massage to decrease blood pressure and improve sleep quality in the elderly}

Health education in the sense of education in general is all planned efforts to influence other people, whether individuals, groups, or communities, so that they do what is expected by the perpetrators of education or health promotion. And this limitation implies the elements of input (targets and educators of education), process (planned efforts to influence others), and output (doing what is expected). The expected result of a health promotion or education is health behavior, or behavior to maintain and improve health that is conducive to the goals of health promotion [15]. Health education is important in improving health status. One of the inhibiting factors, in increasing public awareness to control blood pressure and reducing patient compliance with hypertension drugs, includes low levels of knowledge, cultural influences and the lack of health information. Health promotion measures have been shown to significantly lower blood pressure and are suitable for a wide segment of the population [28]. The role of nurses in health promotion is not only proven capable in disease management but has a broad contribution to the development of nursing science [29]. The selection of audiovisual as a media for health education was well received by the respondents. This method provides health education that is more interesting and not rigid; this education displays motion, images and sounds, while counseling with print media displays text, images and voices of the extension workers that seem very formal. According to Maulana 2009 in Kapti 2010, audiovisual media provides a stimulus for hearing and vision so that the results obtained are more maximal [30]. These results can be achieved because the five senses that transmit knowledge the most to the brain are the eyes (75-87\%); whereas $13-25 \%$ of knowledge is acquired through the other senses.
The results of the study are in accordance with the research of Iporra (1996) the results show that there are differences in the knowledge and skills of respondents after being given the audiovisual education method. This study is also in line with research conducted by Aulia 2014 which showed that there was a significant difference in the improvement of self-management of hypertension patients (jogging, aerobics, and regularity in taking antihypertensive drugs) ( $p=0.002$ ) after being given education with the Behavioral Activation module between the intervention group and the intervention group. Control group [25] participants in the experimental group had a significantly higher average duration of jogging (40.48 min/day) and regularity of taking medication (6 times/week) than the control group. Changes in behavior in a person can occur through the learning process. Learning is defined as the process of changing behavior based on previous behavior. In the learning process, there are three main interrelated elements, namely input, process, and output [12]. Health education is not only limited to the dissemination of health information but also raises one's motivation, skills, and confidence in taking action to improve health [2]. Health education is inseparable from activities or efforts to convey health messages to communities, groups, or individuals. Relaxation massage is generally considered a therapeutic tool without a scientific basis. Massage therapy is another type of CAM practice that is often used to treat muscle pain, injury, and stiffness. This method has recently been used to treat mental and emotional problems, including stress, anxiety, and depression. Massage therapy is also considered a relaxation technique that can help reduce tension and induce feelings of calm and deep relaxation [30]. The American Massage Therapy Association defines massage as the manual manipulation of soft tissues, including holding, causing movement, and/or applying pressure to the body. It was reported that massage therapy effectively improves the health and well-being of elderly individuals, which may be important as the elderly population increases in various countries around the world [31]. In a study examining the effects of massage therapy on the elderly, showed that massage therapy improves well being and reduces stress perceptions among the elderly [30]. In addition, also reported the relationship between massage therapy and health improvement outcomes in the elderly [20].

Relaxation massage is known to affect the activation of arterial and venous blood flow in the lymphatic system and in connective tissue and muscles. Musculocutaneous stimuli act on receptors for touch, pressure, heat, vibration, and pain and are transduced through the peripheral and autonomic nervous systems to the central nervous system (spinal cord and brain). Triggers of neurochemical reactions such as relaxation, increased sleep, calmness, well-being, decreased heart and respiratory rate, peristalsis, increased diuresis, reduced dysmenorrhea, and restoration of homeostasis can be observed clinically [28]. Several studies have shown an improvement in insomnia complaints after anti-stress 
massage. In a study of postmenopausal women with insomnia, we found improvements in sleep patterns by polysomnography, including significant reductions in REM latency and Stage 1 sleep, and significant improvements in stage 3 and 4 sleep, as well as significant improvements in anxiety and depression. SleepDiary analysis showed that all participants fell asleep faster, experienced improved sleep quality and felt better when they woke up [29]. In the study of Hachul, et al., 2011, this study also conducted a controlled trial which found a significant reduction in depression, insomnia and an increase in quality of life. Non-pharmacological "sleep hygiene" interventions that target the source of the problem can be applied first in insomnia, and should be continued even when medication is needed [28], [29]. The benefits of relaxing massage to reduce anxiety and improve mood may be related to changes in EEG activity, decreased cortisol levels and increased activity of the parasympathetic nervous system, which acts automatically to calm the body and brain during stress. Functional brain imaging studies show that changes occur in many brain areas involved in emotion regulation and stress response including the amygdala and hypothalamus [30]. Confirmed these findings, showing that massage therapy reduces anxiety and stress, increases frontal delta activity, reduces frontal alpha and beta activity, and shifts frontal alpha asymmetry from right hemisphere to left hemisphere dominance [31], [32].

\section{Conclusion}

The conclusion of research on health education and relaxation massage can lower blood pressure better than the patient's initiative to ask questions. Health education and relaxation massage can improve sleep quality better than the patient's initiative to ask questions and lower blood pressure better than the patient's initiative to ask.

The recommendation of this research is the implementation of health education and massage relaxation needs to be socialized to the family level so that family members can play a maximum role in improving the health of the elderly in the family. The implementation of health education and massage relaxation is expected to be continuously fostered by the local Village Midwife.

\section{Ethical Clearance}

Ethical permission is approval from the Health Polytechnic Research Ethics Commission of the
Ministry of Health of Denpasar Bali, this research does not use human and animal experiment objects.

\section{References}

1. Kementerian Kesehatan RI. Infodatin Pusat Data dan Informasi Kemeterian Kesehatan RI Situasi Osteoporosis di Indonesia, Jakarta; 2014.

2. Riset Kesehatan Dasar (Riskesdas). Badan Penelitian dan Pengembangan Kesehatan Kementerian RI, Jakarta 2013; 2014. https://doi.org/10.14203/press.298

3. World Health Organization. Health Education: Concept, Effective Strategic and Core Competence. Estearn Mediteranian. Geneva: World Health Organization; 2012.

4. World Health Organization. Ageing and Health. Geneva: World Health Organization; 2020. Available from: https://www.who. int/news-room/fact-sheets/detail/ageing-and-health\#: .2018. [Last accessed on 2020 Sep 29]. https://doi.org/10.1037/ e320122004-001

5. Yusharmen. Triple Burden Ancam Lansia; 2013. Available from: http://www.depkes.go.id/article/view/13100008/triple-burdenancam-lansia.html. [Last accessed on 2020 Oct 02]

6. Dinas Kesehatan Provinsi Bali. Profil Kesehatan Propinsi Bali: Dinkes Denpasar; 2017

7. Dinas Kesehatan Gianyar Bali. Profil Kesehatan Kabupaten Gianyar: Dinkes Gianyar; 2018.

8. Aronow WS, Fleg JL, Pepine CJ, Artinian NT, Bakris G, Brown AS, et al. ACCF/AHA 2011 expert consensus document on hypertension in the elderly: A report of the American college of cardiology foundation task force on clinical expert consensus documents. Circulation. 2011;123(21):2434-506. https://doi. org/10.1161/cir.0b013e31821daaf6

PMid:21518977

9. Field T. Massage therapy research review. Complement Ther Clin Pract. 2014;20(4):224-9.

PMid:25172313

10. Kapti RE. Efektivitas Audiovisual Sebagai Media Penyuluhan dan Sikap Ibu Dalam Tatalaksana Balita Dengan Diare di Dua Rumah Sakit di Kota Malang, Tesis. Indonesia: Universitas Indonesia; 2010. https://doi.org/10.36746/jka.v12i2.36

11. Al-Tabany TI. Mendesain Model Pembelajaran Inovatif, Progesif, dan Kontekstial. Jakarta: PT Kharisma Putra Utama; 2017.

12. Yulianti, A. Komponen-Komponen pendidikan. Makalah Tugas Mata Kuliah Landasan Pendidikan, Universitas IBN Khaldun Bogor; 2016.

13. Badan Penyelenggara Jaminan Sosial Kesehatan. Panduan Praktek Pelayanan Kebidanan dan Neonatal; 2014. Available from: https://www.bpjskesehatan.go.id/bpjs/dmdocuments/ c2145cecc7a821fe00e19d57e67bc950.pdf. [Last accessed on 2017 Agu 27]. https://doi.org/10.33486/jk.v9i1.59

14. Kholid A. Promosi Kesehatan Dengan Pendekatan Teori Perilaku, Media dan Aplikasinya (Cetakan I). Jakarta: PT Rajagrafindo Persada; 2012.

15. Sastroasmoro S, Ismael SD. Dasar Metodologi Penelitian Klinis. $5^{\text {th }}$ ed. Jakarta: Sagung Seto; 2014.

16. Pocock SJ. Clinical Trial. A Practical Approach. New York: A Willey Medical Publication; 2008

17. Aronow WS, Fleg JL, Pepine CJ, Artinian NT, Bakris G, Brown AS, et al. ACCF/AHA 2011 expert consensus document on hypertension in the elderly: A report of the American college of cardiology foundation task force on clinical expert 
consensus documents developed in collaboration with the American academy of neurology, American geriatrics society, American society for preventive cardiology, American society of hypertension, American society of nephrology, association of black cardiologists, and european society of hypertension. J Am Soc Hypertens. 2011;5(4):259-352. https://doi.org/10.1016/j. ycar.2012.02.075

PMid:21771565

18. Eshkoor SA, Hamid TA, Shahar S, Ng CK, Mun CY. Factor affecting hypertension among the Malaysian elderly. J Cardiovasc Dev Dis. 2016;3(1):8. https://doi.org/10.3390/ jcdd3010008

PMid:29367559

19. Knutson $\mathrm{KL}$, van Cauter E, Rathouz PJ, Yan LL, Hulley SB Liu K, Lauderdale DS. Association between sleep and blood pressure in midlife: The CARDIA sleep study. Arch Intern Med. 2009;169(11):1055-61. https://doi.org/10.1001/ archinternmed.2009.119

PMid: 19506175

20. Fung MM, Peters $K$, Redline $S$, Ziegler MG, Israel $S A$, Connor EB, et al. Decreased slow wave sleep increases risk of developing hypertension in elderly men. Am Heart Assoc. 2011;58(4):596-603. Available from: http://www.hyper. ahajournals.org. [Last accessed on 2020 Jun 02]. https://doi. org/10.1161/hypertensionaha.111.174409

21. Tiwari S, Sinha AK, Patwardhan K, Gehlot S, Gambhir IS, Mohapatra SC. Prevalence of health problems among elderly: A study in a rural population of Varanasi. Indian J Prev Soc Med. 2010;41(3-4):226-230.

22. Rahajeng E, Tuminah S. Prevalensi Hipertensi dan Determinannya di Indonesia. Vol. 59. Jakarta: Pusat Penelitian Biomedis dan Farmasi Badan Penelitian Kesehatan Departemen Kesehatan RI, Majalah Kedokteran Indonesia; 2009. p. 580-7. https://doi.org/10.6066/jtip.2013.24.2.121

23. Jain R. Pengobatan Alternative untuk Mengatasi Tekanan Darah. Jakarta: Gramedia Pustaka Utama; 2011.

24. Hachul H, Oliveira DS, Bittencourt LR, Andersen ML, Tufik S. The beneficial effects of massage therapy for insomnia in postmenopausal women. Sleep Sci. 2014;7:114-6. https://doi. org/10.1016/j.slsci.2014.09.005

\section{PMid:26483913}

25. Aulia M. Validasi Modul Behavioral Activation Dalam Meningkatkan Manajemen Diri Pasien Hipertensi di Puskesmas, Tesis; 2014.

26. Roth T, Coulouvrat C, Hajak G, Lakoma MD, Sampson NA, Shahly $\mathrm{V}$, et al. Prevalence and perceived health associated with insomnia based on DSM-IV-TR; international Statistical Classification of Diseases and related health problems, tenth revision; and research diagnostic criteria/ international classification of sleep disorders, second edition criteria: Results from the America insomnia survey. Biol Psychiatry. 2011;69(6):592-600. https://doi.org/10.1016/j. biopsych.2010.10.023

PMid:21195389

27. Patel D, Steinberg J, Patel P. Insomnia in the elderly: A review. J Clin Sleep Med. 2018;14(6):1017-24.

PMid:29852897

28. Kamel NS, Gammack JK. Insomnia in the elderly: Cause, approach, and treatment. Am J Med. 2006;119(6):463-9. PMid:16750956

29. Hong WH. Evidence-based nursing practice for health promotion in adults with hypertension: A literature review. Asian Nurs Res (Korean Soc Nurs Sci). 2010;4(4):227-45. PMid:25031205

30. Star K. Therapeutic Massage for Anxiety and Panic Disorder 2018. Available from: http://www.verywellmind.com. [Last accessed on 2020 Oct 11].

31. Nakano H, Kodama T, Ueda T, Mori I, Tani T, Murata S. Effect of hand and foot massage therapy on psychological factors and EEG activity in elderly people requiring long-term care: A randomized cross-over study. Brain Sci. 2019;9(3):54. https:// doi.org/10.3390/brainsci9030054 PMid:30836612

32. Edwards ES, Sackett SC. Psychosocial variables related to why women are less active than men and related health implications. Clin Med Insights Womens Health. 2016;9 Suppl 1:47-56. https://doi.org/10.4137/cmwh.s34668

PMid:27398045 